\title{
An Empirical Assessment of Alternative Discretionary Accrual Models: Evidence from Earnings Restatements
}

\author{
Huishan Wan ${ }^{1}$ \\ ${ }^{1}$ Department of Accounting, University of Northern Iowa, Cedar Falls, IA 50613, USA. \\ Correspondence: Huishan Wan, Department of Accounting, University of Northern Iowa, Cedar Falls, IA 50613, USA. \\ Phone: 1-319-273-6298. E-mail: huishan.wan@uni.edu
}

Received: October 21, 2018

Accepted: October 26, 2018

Online Published: November 14, 2018

doi:10.5430/afr.v7n4p138

URL: https://doi.org/10.5430/afr.v7n4p138

\begin{abstract}
Using a sample of firms that restated earnings, this study seeks to evaluate the performance of alternative discretionary accrual models along two dimensions: earnings management detection and accuracy (the ability to accurately estimate the magnitude of managed earnings). The findings of this study are important for three reasons. First, discretionary accrual models play a prominent role in several streams of accounting research, especially in earnings management research. Thus, the ability of discretionary accrual models to isolate the discretionary component from the non-discretionary component of total accruals is critical. Second, there is concern about earnings management inferences drawn from discretionary accrual estimates generated by existing discretionary accrual models. One major concern is that extant discretionary accrual models are mis-specified, which results in misleading inferences about earnings management behavior. Finally, there is lack of consensus in the literature on the relative performance of discretionary accrual models. Using earnings restatements data, I investigate the relative performance of four extant discretionary accrual models and a Modified Forward-Looking Model. The findings indicate that the Modified Forward-Looking Model is better specified and outperforms the other models both in terms of detecting earnings management and in estimating the magnitude of managed earnings.
\end{abstract}

JEL Classification: M41; C21; C13

Keywords: discretionary accrual models, financial statements restatement, earnings management, accuracy

\section{Introduction}

Discretionary (abnormal) accrual models play a prominent role in several streams of accounting research especially earnings management (Kasznik 1999, Teoh et al. 1998, Dechow et al. 2003, Pravitt et al. 2009) and earnings quality (Beniesh and Vargus 2002, Frankel et al. 2002, Larker and Richardson 2003, Xie et al. 2003, Larker et al. 2007, Ali et al. 2007). These streams of research are of interest not only to academics, but also to practitioners and regulators. It is generally assumed that discretionary accruals is the portion of accruals over which management exercises discretion, and this estimated portion of accruals is often used as a proxy for earnings management. Therefore, the ability of discretionary accrual models to isolate the discretionary component from the non-discretionary component of total accruals is critical.

This paper seeks to assess the relative performance of various discretionary accrual models using a sample of firms that issued financial statements restatements from 1994 to 2005 (GAO 2002, 2006). I examine the discretionary accrual models along two dimensions: (1) the ability to detect earnings management that exists; and (2) the ability to estimate the magnitude of managed earnings. This research is important because there is considerable concern in the literature regarding the validity of inferences using the discretionary accruals estimates generated from extant discretionary accrual models. One major concern is that the models are mis-specified because of the correlated omitted variables. Thus, the models can result in misleading inferences about earnings management (McNichols 2000).

Using firms that have restated earnings provides an ideal sample for this evaluation because: (1) it is known that earnings management has occurred to certain extent; and (2) the magnitude of managed earnings is measurable. The studies by the General Accounting Office (GAO 2002, 2006) identify financial statement restatement firms that involved accounting irregularities resulting in material misstatements of financial results from 1994 to 2005. The GAO defines an accounting irregularity as "an instance in which a company restates its financial statements because 
they were not fairly presented in accordance with generally accepted accounting principles (GAAP)" (GAO 2002, p.2). With the GAO reports, I read the announcements and the 10-Ks to eliminate the restatements that do not affect earnings and the restatements only caused by errors. To measure the magnitude of managed earnings, I calculate the difference between the originally reported and restated earnings. Under the assumption that firms manipulate earnings via discretionary accruals, the difference may be considered as a proxy for the accruals over which management exercised discretion. Since management's accrual discretion is unobservable, previous studies generally do not have objective benchmarks to evaluate discretionary accrual measures. In contrast, the earnings restatement setting provides an ex-post observable measure that reasonably captures management's discretion. Using the difference between originally reported and restated earnings as a measure of discretionary accruals (managed earnings), I then compare the estimated discretionary accruals from various discretionary accrual models with this benchmark discretionary accruals to test how accurate each discretionary accrual model is in estimating the magnitude of managed earnings. (Note 1) Furthermore, for restatement firms, I can identify the reasons for the restatement (for example, revenue management or expense management). This provides the opportunity to evaluate the ability of alternative discretionary accrual models to detect earnings management that was accomplished through revenues versus expenses.

I am motivated to undertake this evaluation for three reasons. First, prior studies have yielded inconsistent results regarding the relative performance of alternative discretionary accrual models (Note 2). Thus, which discretionary accrual model performs the best in terms of detecting earnings management is still an open empirical question. In addition, a number of refinements to discretionary accrual models have been introduced (Note 3), but the descriptive validity of these refined models has not been subject to rigorous testing. Hence, further investigation is warranted. In this study, I evaluate several widely used discretionary accrual models along with some more-refined models (Note 4).

Second, this study complements the prior studies that evaluate discretionary accrual models using simulation techniques (Dechow et al. 1995, Kang and Sivaramakrishnan 1995, Kothari et al. 2005). Although simulation studies are informative, there is no guarantee that accrual behavior of simulated data is reflective of real earnings management. Moreover, these studies use parameter values estimated from observed data that to some degree is likely managed. Thus, the external validity of these studies may be limited. Using real instances of earnings management enhances the external validity of studies designed to detect earnings management.

Finally, several papers find that the existing discretionary accrual models fail to generate accurate estimates of magnitudes of discretionary accruals (Thomas and Zhang 2000, Fields et al. 2001). Therefore, there is demand for better discretionary accrual models that more accurately estimate the portion of accruals that are managed (i.e. discretionary accruals) (Kothari 2001). This paper responds to this call by proposing a modified version of the Forward-Looking Model, the Modified Forward-Looking Model, which is better specified (see section 2 for detailed discussion of alternative discretionary accrual models). In addition, the empirical results indicate that it is a more accurate model than the others.

I use 866 firm-year observations that issued financial statements restatements from 1994 to 2005 from the GAO reports (GAO 2002, 2006) as the test sample. The control sample consistes of the non-restatement firms in the same 2-digit-SIC industry and year as those of the restatement firms. With these samples I performce univariate test, contingency-table test, logistice regression analysis, and accuracy analysis to evaluate differenct discretionary accrual models. The findings indicate that the Modified Forward-Looking Model is better specified and outperforms the other models both in terms of detecting earnings management and in estimating the magnitude of managed earnings

This study makes several contributions to the extant literature. First, using the ex post observed earnings restatement amount enables me to calibrate the performance of alternative widely used discretionary accrual models in terms of the ability to estimate the magnitude of managed earnings.

Second, this paper provides evidence of using both discretionary and non-discretionary accruals to evaluate the performance of the discretionary accrual models in detecting earnings management. Prior studies mainly focus on discretionary accruals and do not include non-discretionary accruals in the regression. When I evaluate the discretionary accrual models' ability to detect earnings management, I include both discretionary accruals and nondiscretionary accruals as independent variables. The reasoning is as follows. Ideally, if a discretionary accrual model does a good job of isolating the discretionary accruals from total accruals, the discretionary accruals should contain all the information useful for detecting earnings management while the non-discretionary accruals should have no information for identifying when earnings management has occurred. If a discretionary accrual model 
incorrectly identifies discretionary accruals as non-discretionary accruals, non-discretionary accruals will contain some earnings management information. Thus, including both discretionary and non-discretionary accruals in the regression provides additional insights in evaluating the alternative discretionary accrual models.

This paper also supplements Jones, Krishnan, and Melendrez (2008) in the two dimensions. First, this paper investigates the forward-looking discretionary accruals model developed in Dechow et al. (2003) while Jones et al. (2008) omit Dechow et al. (2003) model. The analyses provide convincing evidence that Dechow et al. (2003) model performs better than baseline models studied in Jones et al. (2008). Second, this paper focuses on restatement firms reported in GAO 2002 and GAO 2006 while Jones et al. (2008) primarily investigate firms with fraudulently overstated earnings and conduct an additional test on firms with voluntary restatements in GAO 2002.

The remainder of the paper is organized as follows. Section 2 describes the alternative discretionary accrual models. Section 3 discusses the research design. Section 4 presents the sample selection and results. Section 5 concludes.

\section{Discretionary Accrual Models}

In this section, I discuss the discretionary accrual models used in prior literature. The purpose of a discretionary accrual model is to decompose total accruals into two components: non-discretionary accruals and discretionary accruals. Discretionary accruals is the component of earnings that is deemed to reflect the portion of earnings that is managed. The implementation of the models starts with total accruals (TACC). I follow Collins and Hribar (2002) and compute Total Accruals as follows (Compustat mnemonics in parentheses):

$\mathrm{TACC}_{\text {it }}=\mathrm{EBXI}_{\mathrm{it}}-\mathrm{CFO}_{\text {it }}$

where $\quad$ TACC - total accruals scaled by beginning total assets $\left(\mathrm{TA}_{\mathrm{it}-1}\right)$;

EBXI - earnings before extraordinary items and discontinued operations (IBC) scaled by beginning total assets $\left(\mathrm{TA}_{\mathrm{it}-1}\right)$;

$\mathrm{CFO}$ - Cash Flows from Operation (OANCF- XIDOC) scaled by beginning total assets $\left(\mathrm{TA}_{\mathrm{it}-1}\right)$. (Note 5)

In order to implement the models, an estimation period and a test period need to be specified. In this study, I treat all the non-restatement firm-years as the estimation period and all the restatement firm-years as the test period. For most of the models, the parameters are estimated in the estimation period using the following regression:

$\mathrm{TACC}=\beta \mathrm{X}+\varepsilon$

Where $\mathrm{X}-$ vector of independent variables (scaled by beginning total assets) included in the model; $\varepsilon$ - the error term. follows:

With the estimated parameters, the non-discretionary accruals (NDA) in the test period are calculated as

$$
N D A=\hat{\beta} X
$$

Then the discretionary accruals (DA) are calculated as follows:

$\mathrm{DA}=\mathrm{TACC}-\mathrm{NDA}$

In this study I examine the Jones Model (Jones 1991), the Modified Jones Model (Dechow et al 1995), the Lagged Model (Dechow et al 2003), the Performance-Matched Modified Jones Model (Kothari et al 2005), and the Modified Forward-Looking Model.

\subsection{The Jones Model}

The Jones (1991) Model attempts to control for the effects of changes in a firm's economic circumstances on nondiscretionary accruals. It expresses accruals as a function of the change in Sales Revenues and the level of gross Property, Plant, and Equipment (PPE). More specifically, it is estimated for each two-digit SIC-year grouping as follows:

$\mathrm{TACC}_{\mathrm{it}}=\alpha+\beta_{1}\left(1 / \mathrm{TA}_{\mathrm{it}-1}\right)+\beta_{2}\left(\Delta \mathrm{SALES}_{\mathrm{it}}\right)+\beta_{3} \mathrm{PPE}_{\mathrm{it}}+\varepsilon_{\mathrm{it}}$

where $\quad \mathrm{TACC}_{\mathrm{it}}=$ total accruals scaled by beginning total assets $\left(\mathrm{TA}_{\mathrm{it}-1}\right)$

$\mathrm{TA}_{\text {it }-1}=$ firm i's year $\mathrm{t}-1$ total assets (AT);

$\triangle$ SALES $_{\text {it }}=$ the change in firm i's sales (SALE) from year t- 1 to $t$ scaled by beginning total assets $\left(\mathrm{TA}_{\mathrm{it}-1}\right)$;

$\mathrm{PPE}_{\mathrm{it}}=$ firm i's year $t$ gross property, plant, and equipment (PPEGT) scaled by beginning total assets (TA it-1); 
$\varepsilon_{\text {it }}=$ the error term.

The idea of the Jones Model is that Sales Revenues control for current non-discretionary accruals, while gross PPE controls for non-discretionary accruals related to depreciation expense. Thus, the Jones Model makes two key assumptions. First, Sales Revenues are assumed to be unmanaged so that they can be used as an explanatory variable. If earnings are managed through Sales Revenues, then the Jones Model will remove part of the managed earnings from the discretionary accruals. The second assumption is that changes in current assets and current liabilities are both driven by changes in Sales Revenue. This assumption seems restrictive because current liabilities such as payables are more likely to be related to expenses than to revenues. Thus, it suffers from an omitted variables problem (Kang and Sivaramakrishnan 1995, Kang 1999).

\subsection{The Modified Jones Model}

The Modified Jones (MJ) Model proposed by Dechow et al. (1995) is designed to eliminate the tendency of the Jones Model to measure discretionary accruals with error when discretion is exercised over revenues. The modification relative to the Jones Model is that the change in Sales Revenues is adjusted for the change in Receivables. The Modified Jones Model assumes that all credit sales are discretionary. This is based on the reasoning that it is easier to manage credit sales than cash sales.

Following Kothari et al. (2005), I estimate the Modified Jones Model for each two-digit SIC-year grouping as follows:

$$
\mathrm{TACC}_{\mathrm{it}}=\alpha+\beta_{1}\left(1 / \mathrm{TA} \mathrm{it}_{\mathrm{t}-1}\right)+\beta_{2}\left(\Delta \mathrm{SALES}_{\mathrm{it}}-\Delta \mathrm{AR}_{\mathrm{it}}\right)+\beta_{3} \mathrm{PPE}_{\mathrm{it}}+\varepsilon_{\mathrm{it}}
$$

where $\quad \Delta \mathrm{AR}_{\mathrm{it}}=$ the change in firm i's accounts receivable from year $\mathrm{t}-1$ to $\mathrm{t}(\mathrm{RECCH})$ scaled by beginning total assets $\left(\mathrm{TA}_{\mathrm{it}-1}\right)$.

\subsection{The Lagged Model}

Even though the Modified Jones Model makes a correction for earnings management through credit sales, concerns remain about its estimation. The concerns are the Modified Jones Model assumes all credit sales are discretionary and the TACC this year is predictable based on last year's TACC. To address these concerns, the Lagged Model (LG) proposed by Dechow et al (2003) makes two adjustments to the Modified Jones Model. First, the Modified Jones Model assumes all credit sales are discretionary which induces a positive correlation between discretionary accruals and current sales growth. The Lagged Model treats the expected change in Accounts Receivable for a given change in Sales as non-discretionary. Second, the Lagged Model includes the lagged total accruals because a portion of total accruals is predictable based on last year's total accruals (Beneish 1997, Chambers 1999).

The Lagged Model is estimated for each two-digit SIC-year grouping as follows:

$$
\text { TACC }_{i t}=\alpha+\beta_{1}\left(1 / \mathrm{TA}_{\mathrm{it}-1}\right)+\beta_{2}\left((1+\mathrm{k}) \Delta \text { SALES }_{\mathrm{it}}-\Delta \mathrm{AR}_{\mathrm{it}}\right)+\beta_{3} \mathrm{PPE}_{\mathrm{it}}+\beta_{4} \mathrm{TACC}_{\mathrm{it}-1}+\varepsilon_{\mathrm{it}}
$$

where $\mathrm{k}-$ the regression coefficient from a regression $\Delta \mathrm{AR}_{\mathrm{it}}=\alpha+\mathrm{k} \Delta \mathrm{SALES} \mathrm{it}_{\mathrm{it}}+\varepsilon_{\mathrm{it}}$ for each two-digit SIC-year grouping;

$\mathrm{TACC}_{\mathrm{it}-1}-$ firm i's total accruals at year t-1 scaled by beginning total assets $\left(\mathrm{TA}_{\mathrm{it}-1}\right)$;

\subsection{The Performance-Matched Modified Jones Model}

Many studies find discretionary accruals are correlated with financial performance (e.g., Dechow et al 1995, McNichols 2000, Kothari et al 2005). Thus, it is important to control for financial performance when estimating discretionary accruals. Kothari et al (2005) are the first to thoroughly examine this issue. They find that the Performance-Matched Modified Jones (PM) Model is better specified and more powerful at detecting earnings management than the traditional Modified Jones Model. Kothari et al (2005) use two ways to control the impact of performance on estimated discretionary accruals: (1) using the discretionary accruals of a firm matched on performance (ROA) and (2) including a measure of performance (ROA) in the discretionary accrual models. Even though several studies employ the first approach (for example, Lowrence et al. 2011, Bostari and Meeks 2008), Keung and Shih (2014) find that performance matching will sysmatically underestimate discretionary accruals. Therefore, in this study, I use the latter approach (Kothari et al. 2016).

The Performance-Matched Modified Jones Model is estimated for each two-digit SIC-year grouping as follows:

$$
\mathrm{TACC}_{\mathrm{it}}=\alpha+\beta_{1}\left(1 / \mathrm{TA}_{\mathrm{it}-1}\right)+\beta_{2}\left(\Delta \mathrm{SALES}_{\mathrm{it}}-\Delta \mathrm{AR}_{\mathrm{it}}\right)+\beta_{3} \mathrm{PPE}_{\mathrm{it}}+\beta_{4} \mathrm{ROA}_{\mathrm{it}}+\varepsilon_{\mathrm{it}}
$$

where $\quad \mathrm{ROA}_{\mathrm{it}}=$ firm i's return on assets of year $\mathrm{t}$. 


\subsection{The Modified Forward-Looking Model}

Dechow et al. (2003) propose another model: the Forward-Looking Model. The Forward-Looking Model makes another adjustment to the Lagged Model. Since accruals by its nature is designed to smooth the reporting of financial transactions, a firm that is growing and anticipates future sales will rationally increase inventory balances. The Modified Jones Model classifies such increases as discretionary accruals reflecting earnings management. Including future sales growth in the model corrects this kind of misclassification. The Forward-Looking Model is estimated as follows:

$$
\begin{gathered}
\mathrm{TACC}_{\mathrm{it}}=\alpha+\beta_{1}\left(1 / \mathrm{TA}_{\mathrm{it}-1}\right)+\beta_{2}\left((1+\mathrm{k}) \Delta \mathrm{SALES}_{\mathrm{it}}-\Delta \mathrm{AR}_{\mathrm{it}}\right)+\beta_{3} \mathrm{PPE}_{\mathrm{it}}+ \\
\beta_{4} \mathrm{TACC}_{\mathrm{it}-1}+\beta_{5} \mathrm{GR}_{-} \mathrm{SALES}_{\mathrm{it}+1}+\varepsilon_{\mathrm{it}}
\end{gathered}
$$

where GR_SALES ${ }_{i t+1}$ - the change in firm i's sales (SALE) from year $t$ to $t+1$ scaled by year $t$ sales.

However, as noted by Dechow et al. (2003, p.359), the information on GR_SALES is not available to financial statement readers until the following year. Therefore, this limits the usefulness of this model (Note 6). Thus, I propose a modified version of the Forward-Looking Model. I make two adjustments to the Forward-Looking Model. First, I use analysts' long-term earnings growth forecasts as a proxy for GR_SALES (Note 7) (McNichols 2000). I refer to this proxy as EST_GROWTH. Second, I add ROA to control for performance (Kothari et al. 2005, McNichols 2000). I estimate the Modified Forward-Looking Model for each two-digit SIC-year group as follows:

$$
\begin{array}{r}
\text { TACC }_{i t}=\alpha+\beta_{1}\left(1 / \mathrm{TA}_{\mathrm{it}-1}\right)+\beta_{2}\left((1+\mathrm{k}) \Delta \mathrm{SALES}_{\mathrm{it}}-\Delta \mathrm{AR}_{\mathrm{it}}\right)+\beta_{3} \mathrm{PPE}_{\mathrm{it}}+ \\
\beta_{4} \mathrm{TACC}_{\mathrm{it}-1}+\beta_{5} \mathrm{EST}_{-} \mathrm{GROWTH}_{\mathrm{it}}+\beta_{6} \mathrm{ROA}_{\mathrm{it}}+\varepsilon_{\mathrm{it}}
\end{array}
$$

where EST_GROWTH ${ }_{\text {it }}$ - the median of analysts' long-term earnings growth forecasts for the last month of year t;

\section{Research Design}

I assess the relative performance of alternative discretionary accrual models along two dimensions: the ability to detect earnings management when it exists and the ability to estimate the magnitude of managed earnings. In this section, I discuss how I assess the performance of alternative accrual models for the pooled sample, the subsample that managed earnings through the revenue side (hereafter REV-Subsample), and the subsample that managed earnings through the expense side (hereafter EXP-Subsample).

\subsection{Detecting Earnings Management}

The restatement firms are the test sample. I select the non-restatement firms in the same 2-digit SIC and year as those of the restatement firms as the control sample (non-restatement sample). For example, Xerox Corp. restated 1998, 1999, 2000, and 2001 fiscal years' financial statements. The industry classification (SIC) code of Xerox Corp. is 3577. Thus, I select all the non-restatement firms with the industry classification code of $35 \mathrm{XX}$ and in the fiscal year 1998 as the control firms for Xerox Corp.'s 1998 restatement.

To evaluate the alternative discretionary accrual models' ability to detect earnings management, I first examine whether the discretionary accruals are significantly different between the test and control samples (I test both mean and median). If a discretionary accrual model generates a significant difference between the discretionary accruals of restatement and non-restatement samples (mean and median), then it is deemed to be a good model for identifying the existence of earnings management.

Second, I conduct univariate contingency-table tests for the association of high versus low discretionary accruals and whether or not a firm had financial statements restatement. I assign the firms to five quintiles based on the absolute value of the discretionary accruals. I then conduct contingency-table tests on the first (lowest level of discretionary accruals) and the fifth (highest level of discretionary accruals) quintiles. A well specified discretionary accrual model should generate a relatively high number of restatement firms assigned to the fifth (high discretionary accruals) quintile and a relatively low number of restatement firms assigned to the first (low discretionary accruals) quintile. The hypothesis (in alternative form) is that the proportion of restatement firms in the high discretionary accruals quintile is greater than the proportion of restatement firms in the low discretionary accruals quintile.

Third, I conduct logistic regression analyses to determine how well the discretionary versus non-discretionary components of accruals from each model predict the likelihood of restatement. I run the following logistic regression:

$$
\begin{aligned}
& \text { RESTATE }=\beta_{0}+\beta_{1} \mathrm{DA}^{\mathrm{i}}+\sum \beta_{\mathrm{i}} \mathrm{IND}_{\mathrm{i}}+\sum \beta_{\mathrm{t}} \mathrm{YEAR}_{\mathrm{t}}+\varepsilon \\
& \text { RESTATE }=\beta_{0}+\beta_{1} \mathrm{DA}^{\mathrm{i}}+\beta_{2} \mathrm{NDA}^{\mathrm{i}}+\sum \beta_{\mathrm{i}} \mathrm{IND}_{\mathrm{i}}+\sum \beta_{\mathrm{t}} \mathrm{YEAR}_{\mathrm{t}}+\varepsilon
\end{aligned}
$$


Where RESTATE - a dummy variable equal to one if the firm-year observation is restated and zero otherwise;

$D A^{i}$ - discretionary accruals estimate according to model $\mathrm{i}$

$\mathrm{NDA}^{\mathrm{i}}$ - non-discretionary accruals estimate according to model $\mathrm{i}$

$\varepsilon$ - error term

In evaluating the discretionary accrual models' ability to detect earnings management, prior studies tend to focus on the role of discretionary accruals and employ models like model (1) in testing for an association between earnings management and discretionary accruals. In this study, I also include non-discretionary accruals (NDA) in the logistic regression (like in model (2)). The reasoning is as follows. Ideally, if a discretionary accrual model does a good job of isolating the discretionary accruals from total accruals and discretionary accruals are assumed to be used to manage earnings, then the non-discretionary accruals should play a minimal role in detecting earnings management. Thus, I expect $\beta_{1}$ to be significantly positive and $\beta_{2}$ to be insignificant. If a discretionary accrual model incorrectly identifies some discretionary accruals as non-discretionary accruals, then non-discretionary accruals will contain some earnings management information. Thus, if $\beta_{2}$ is significant, then I conclude that the model does not do a good job of isolating the component of accruals used to manage earnings.

\subsection{Accuracy Analyses}

Using the original and restated accounting data, I calculate the benchmark discretionary accruals: DA* $=$ Earnings

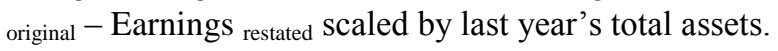

I then calculate the following three metrics to assess the accuracy of each model.

1. Bias: the difference between the estimated discretionary accruals and the benchmark discretionary accruals, DA - DA*. Discretionary accrual models that generate insignificant bias (in terms of mean and median values) are deemed to be more appropriate models for detecting earnings management.

2. Accuracy: absolute value of the bias: $\mid \mathrm{DA}-\mathrm{DA} *$.

3. Ranking of Accuracy: This test is based on firm-year-specific rankings. For each observation, models are ranked from first to fifth based on the value of accuracy. Thus, this test offers a different perspective: it ignores magnitudes of differences. In other words, this test potentially favors models that perform well for most firm-years, perhaps by a small margin, and not perform well occasionally (even if by a large margin).

\section{Sample and Results}

\subsection{Sample Description and Descriptive Statistics}

The financial statements restatement sample is based on the GAO reports (GAO 2002, 2006) which identify firms involved in accounting irregularities resulting in material misstatements of financial results. (Note 8) Those two reports identifies 1,966 companies that made 2,309 financial statement restatement announcements during January 1997 to September 2005 (Note 9). For each of the restatement announcements, I search LEXIS-NEXIS Business for the restatement announcement news to identify the restated fiscal years. Next, I search 10K-Wizard and EDGAR for the original and restated financial statements. For this study, I exclude quarterly restatements to avoid estimation problems associated with seasonality of revenues and expenses for certain industries, which eliminates 926 firms. I then exclude restatements that do not affect earnings which eliminates another 225 firms. In addition, I delete financial services firms and delete observations without sufficient data to estimate discretionary models. The final restatement sample consists of 371 firms with 866 firm-year observations. Panel A of Table 1 describes the sample selection process. 
Table 1. Sample Composition

Panel A: Description of Restatement Sample

\begin{tabular}{|c|c|c|}
\hline Restatement Firms & & 1,966 \\
\hline \multicolumn{3}{|l|}{ Less: } \\
\hline Quarterly restatements & (926) & \\
\hline Restatements do not affect earnings & $(225)$ & \\
\hline Analysts forecasts data are not available & $(261)$ & \\
\hline Financial and Utility firms & (73) & \\
\hline \multirow[t]{2}{*}{ Insufficient financial data to estimate the models } & $(110)$ & \\
\hline & & $(1,595)$ \\
\hline Restatement Sample - Firms & & 371 \\
\hline Restatement Sample - Firm -Years & & 866 \\
\hline
\end{tabular}

Panel B: Distribution of restatement fiscal years

\begin{tabular}{lll}
\hline YEAR & Frequency & $\%$ \\
\hline 1994 & 2 & $0.2 \%$ \\
1995 & 6 & $0.7 \%$ \\
1996 & 13 & $1.5 \%$ \\
1997 & 37 & $4.3 \%$ \\
1998 & 64 & $7.4 \%$ \\
1999 & 77 & $8.9 \%$ \\
2000 & 138 & $15.9 \%$ \\
2001 & 168 & $19.4 \%$ \\
2002 & 178 & $20.6 \%$ \\
2003 & 136 & $15.7 \%$ \\
2004 & 42 & $4.8 \%$ \\
2005 & 5 & $0.6 \%$ \\
\hline Total & 866 & $100.0 \%$
\end{tabular}

Panel C: Restatement Category

\begin{tabular}{lll}
\hline Category & $\mathrm{N}$ & $\%$ \\
\hline Revenue Recognition & 259 & $23.94 \%$ \\
Cost or expense & 457 & $42.24 \%$ \\
Mergers and acquisitions & 43 & $3.97 \%$ \\
Research and development & 4 & $0.37 \%$ \\
Related-party transactions & 15 & $1.39 \%$ \\
Reclassification & 53 & $4.90 \%$ \\
Restructuring & 120 & $11.09 \%$ \\
Securities related & 66 & $6.10 \%$ \\
Other & 65 & $6.01 \%$ \\
\hline Total & 1082 & $100.00 \%$ \\
\hline
\end{tabular}


Panel D. Industry distribution of restated firm years

\begin{tabular}{lll}
\hline Industry (1-digit SIC) & Frequency & Percent \\
\hline 0-1 Agriculture, mining, oil, and construction & 35 & $3.91 \%$ \\
2 Food, tobacco, textiles, paper, and chemicals & 83 & $9.26 \%$ \\
3 Manufacturing, machinery, and electronics & 167 & $18.64 \%$ \\
4 Transportation and communications & 91 & $10.16 \%$ \\
5 Wholesale and retail & 259 & $28.91 \%$ \\
6 Insurance & 52 & $5.80 \%$ \\
7 Services & 172 & $19.20 \%$ \\
8-9 Health, legal, and educational services and other & 37 & $4.13 \%$ \\
Total & 896 & $100.00 \%$
\end{tabular}

Table 1 also reports some general information about the sample. The sample does not concentrate in any particular year. Panel B indicates that most of the observations are from year 1997 to 2004. Panel C shows the restatement category. The most common reason for restatement is Expense Manipulation (42.24\%) followed by Revenue Recognition (23.94\%).

Panel D summarizes the industry composition of the restatements. There is no evidence of industry clustering in the sample. The industries that contain the highest percentage of restatements include: wholesale and retail $(28.91 \%)$, Services (19.20\%), and manufacturing, machinery and electronics (18.64\%).

Table 2 reports the mean coefficient estimates for the paramenters of different discretionary accrual models. The coefficients on (Sales - AR) are positive and the coefficients on PPE are negative, which are consistent with prior studies

Table 2. Implementation of Discretionary Accrual Models

\begin{tabular}{|c|c|c|c|c|c|}
\hline & Jones Model & $\begin{array}{l}\text { Modified Jones } \\
\text { Model }\end{array}$ & Lagged Model & PM Model & Modified FL Model \\
\hline \multirow[t]{2}{*}{$\mathrm{a}$} & -0.058 & -0.058 & -0.043 & -0.054 & -0.047 \\
\hline & -28.79 & -28.68 & -16.08 & -20.95 & -2.46 \\
\hline \multirow[t]{2}{*}{$1 / \mathrm{TA}$} & -0.156 & -0.156 & -0.122 & 0.13 & 0.332 \\
\hline & -3.68 & -3.68 & -3.23 & 4.31 & 2.06 \\
\hline \multirow[t]{2}{*}{$\Delta$ SALES* } & 0.026 & 0.019 & 0.014 & 0.015 & 0.013 \\
\hline & 5.92 & 3.71 & 3.57 & 3.68 & 3.85 \\
\hline \multirow[t]{2}{*}{ PPE } & -0.035 & -0.033 & -0.029 & -0.036 & -0.029 \\
\hline & -8.74 & -8.54 & -7.82 & -10.5 & -8.37 \\
\hline \multirow[t]{2}{*}{ ROA } & & & & 0.271 & 0.266 \\
\hline & & & & 24.57 & 19.34 \\
\hline \multirow[t]{2}{*}{ LTACC } & & & 0.207 & & 0.17 \\
\hline & & & 19.32 & & 16.51 \\
\hline $\mathrm{EST}_{-}$ & & & & & 0.285 \\
\hline GROWTH & & & & & 12.53 \\
\hline Adj. $\mathrm{R}^{2}$ & $26.47 \%$ & $25.65 \%$ & $31.61 \%$ & $34.87 \%$ & $34.11 \%$ \\
\hline
\end{tabular}

This table is based on the average results of 626 2-digit SIC and year observations from 1994-2005. This table presents the regression results for various discretionary accrual models. T-statistics are reported italic below parameter estimates. 
$\triangle$ SALES* refers to SALES for Jones Model, SALES - AR for Modified Jones Model, Lagged Model, and Performance Matched Model, and $(1+\mathrm{k})$ SALES - AR for Modified Forward-Looking Model. Please refer to Appendix A for variables definitions.

\subsection{Earning Management Detection Dnalyses}

For earnings management detection analyses, I perform three tests: univariate comparison of discretionary accruals of control and test samples, contingency table tests, and logistic regression analyses.

\subsubsection{Comparison of Discretionary Accruals}

Table 3 investigates alternative discretionary accrual models' ability to generate significant differences of discretionary accruals between non-restatement and restatement firms. Both mean and median tests indicate that the Performance Matched Model and the Modified Forward-Looking Model, generate significant differences of discretionary accruals between non-restatement and restatement firms. For example, the Modified Forward-Looking Model generates an average difference of 0.021 between the two samples, which means the restatement sample has higher discretionary accruals than the non-restatement sample and the difference is $2.21 \%$ of last year's total assets. This difference is significant at $0.03 \%$ level. This test also shows the importance of performance matching. The Performance Match Model and the Modified Forward-Looking Model which control for firm performance, generate significant results and they outperform their counterpart models without performance matching.

Table 3. Comparison of discretionary accruals

\begin{tabular}{|c|c|c|c|c|c|c|c|c|c|c|}
\hline \multirow[b]{3}{*}{ DA_J } & \multicolumn{5}{|l|}{ Mean } & \multicolumn{5}{|l|}{ Median } \\
\hline & $\begin{array}{l}\text { Nonrestated } \\
\text { firms }\end{array}$ & $\begin{array}{l}\text { Restated } \\
\text { firms }\end{array}$ & Diff. & $\mathrm{t}$ value & & $\begin{array}{l}\text { Nonrestated } \\
\text { firms }\end{array}$ & $\begin{array}{l}\text { Restated } \\
\text { firms }\end{array}$ & Diff. & $\mathrm{z}$ value & \\
\hline & 0.011 & 0.018 & 0.007 & 1.59 & & 0.018 & 0.021 & 0.003 & 0.65 & \\
\hline DA_MJ & 0.012 & 0.019 & 0.007 & 1.65 & & 0.018 & 0.021 & 0.003 & 0.65 & \\
\hline DA_LG & 0.009 & 0.016 & 0.007 & 1.36 & & 0.014 & 0.017 & 0.003 & 1.23 & \\
\hline DA_PM & 0.002 & 0.017 & 0.019 & 2.78 & $* * *$ & 0.000 & 0.011 & 0.011 & 1.52 & $*$ \\
\hline DA_MFL & 0.001 & 0.022 & 0.021 & 3.61 & $* * *$ & 0.002 & 0.016 & 0.014 & 1.81 & $* *$ \\
\hline OBS & 18,739 & 886 & & & & 18,739 & 886 & & & \\
\hline
\end{tabular}

This table provides result from comparison of discretionary accruals between restatement and non-restatement firms using the estimates from various discretionary accrual models.

DA_i is the discretionary accruals estimated from discretionary accrual model i. ***,**, and * indicate statistical significance at the $1 \%, 5 \%$, and $10 \%$ levels, repectively. For the specification of the discretionary accrual models and definition of the variables, please refer to Appendix A.

\subsubsection{Contingency Table Tests}

Table 4 reports the contingency-table test results. The hypothesis (in alternative form) is that the proportion of restatement firms in the high discretionary accruals quintile is greater than the proportion of restatement firms in the low discretionary accruals quintile. Thus, the tests are one-tailed. Only the Modified Forward-Looking Model generates significant results in the predicted direction. For the Modified Forward-Looking Model, the number of restated firms declines from 215 in the high-discretionary-accruals level to 133 in the low-discretionary-accruals level. That is, in the high-discretionary-accruals level, 215 out of 3921 firms are restated (i.e., 5.48\%), while in the low-discretionary-accruals level, only 133 out of 3788 firms are restated (i.e., 3.39\%). (Note 10) A contingency-table test indicates that this difference is statistically significant at the $0.01 \%$ level. Contingency-table tests for the other models (the Jones Model, the Modified Jones Model, the Lagged Model, and the Performance Matched Model,) generate insignificant differences in proportion of restatement firms in the high versus low discretionary accruals quintiles. 
Table 4. Contingency-Table Test -

Association between absolute value of discretionary accruals and financial statements restatements

\begin{tabular}{|c|c|c|c|c|c|c|c|c|c|c|}
\hline \multirow[b]{2}{*}{ Restated } & \multicolumn{2}{|c|}{ Jones Model } & \multirow{2}{*}{$\begin{array}{l}\text { Modified } \\
\text { Model }\end{array}$} & \multirow{2}{*}{$\begin{array}{l}\text { Jones } \\
\text { No }\end{array}$} & \multicolumn{2}{|c|}{ Lagged Model } & \multicolumn{2}{|c|}{$\begin{array}{l}\text { Performance } \\
\text { Matched Model }\end{array}$} & \multicolumn{2}{|c|}{$\begin{array}{l}\text { Modified } \\
\text { Forward-Looking } \\
\text { Model }\end{array}$} \\
\hline & Yes & No & & & Yes & No & Yes & No & Yes & No \\
\hline High DA & 180 & 3741 & 183 & 3738 & 177 & 3744 & 172 & 3749 & 215 & 3706 \\
\hline Low DA & 174 & 3747 & 172 & 3749 & 164 & 3757 & 154 & 3767 & 133 & 3788 \\
\hline $\mathrm{p}$ value & 0.3090 & & 0.2935 & & 0.2532 & & 0.1681 & & 0.000 & \\
\hline
\end{tabular}

This table reports the results of contingency table tests which examines the association of high versus low discretionary accruals and whether or not a firm had financial statement restatement. I assign firms to quintiles based on the absolute value of the discretionary accruals. I then conduct the contingency table tests on the first (Low DA) and the fifth (High DA) quintiles. A well specified discretionary accrual model should generate a relatively high number of restatement firms assigned to the high DA quintile and a relatively low number of restatement firms assigned to the low DA quintile.

The alternative hypothesis is that the proportion of restatement firms in the high discretionary accruals quintile is greater than the proportion of restatement firms in the low discretionary accruals quintile

For the specification of the discretionary accrual models, please refer to Appendix A.

\subsubsection{Logistic Regression Results}

Table 5 provides results for the logistic regression analyses. Following Phillips, Pincus, and Rego (2003), I include $\triangle \mathrm{CFO}$ (Cash Flows from Operation) to control for the change of fundamental economic performance. I also include $\triangle \mathrm{CFO}^{2}$ to control for the nonlinear relation. I only report the coefficients on DA and NDA for simplicity.

I expect the sign of the DA coefficient to be significantly positive, indicating that the higher the DA, the more likely the firm will restate. I expect the coefficient on NDA to be insignificant or significantly negative. If NDA is insignificant, this implies that NDA does not play any role in predicating whether a firm will restate. If NDA is significantly negative, this implies that the higher the NDA, the less likely a firm will restate. For both situation, I conclude that the discretionary accrual model is properly specified.

Panel A reports the results from a regression with only DA as an independent variable. The results show that the Performance Matched Model and the Modified Forward-Looking Model generate significant positive coefficients for DA. Panel B reports the results from a regression including NDA as an additional independent variable. The results show that only the Modified Forward-Looking Model generates significant positive coefficient for DA and insignificant coefficient for NDA. For the Performance Matched Model, the coefficient on DA becomes insignificant after including NDA as an additional independent variable. All other models have insignificant coefficients on DA. Thus, the results of Panel A and B together suggest that including NDA in the regression is helpful to evaluate the performance of the discretionary accrual models (Note 11).

Overall, the Modified Forward-Looking Model survives all three tests for earnings management detection, which suggests that this model outperforms all other models in terms of detecting the existence of earnings management. 
Table 5. Earnings management detection - logistic regression

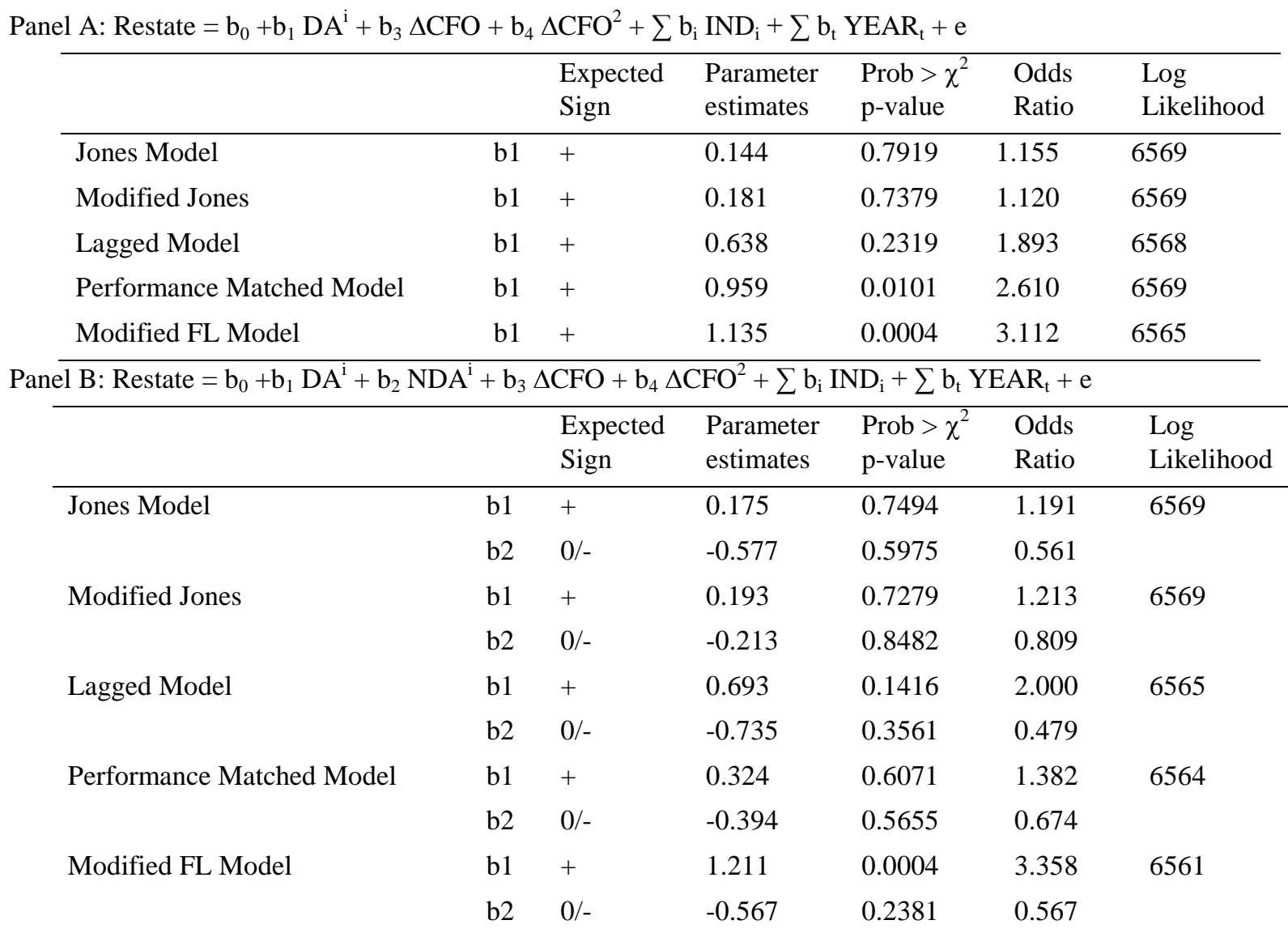

This table presents the results from logistic regression analyses. The predicted sign for DA is significant positive. The predicted sign for NDA is insignificant or significant negative.

Restate is a dummy variable which equals 1 for restatement firm years and 0 for non-restatement firm years. DA ${ }^{i}$ is discretionary accruals estimated by Model i. NDA ${ }^{\mathrm{i}}$ is non-discretionary accruals estimated by Model i. Please refer to Appendix A for other variables definitions.

\subsection{Accuracy Analyses}

Table 6 reports the accuracy results. I expect a well-specified model will generate bias and accuracy (absolute value of bias) measures that are not significantly different from zero. Recall that bias is measured as the difference between the discretionary accrual estimates from the discretionary accrual models and the benchmark discretionary accruals. The accuracy is the absolute value of bias. Panel A shows that the Modified Forward-Looking Model generates the smallest bias (mean -0.003 and median -0.003 , both are not significantly different from zero.). On the other hand, all the other models generate significant bias, which means these models generate biased estimates of discretionary accruals.

For accuracy measure, both mean and median values for all the models are significantly different from zero at 0.01 level. This is consistent with Thomas and Zhang (2000)'s finding that all extant discretionary accrual models are not very accurate in estimating the amount of earnings that is managed.

Panel B reports the results of the firm-year-specific rankings of the discretionary accrual models in terms of accuracy. It shows that the Modified Forward-Looking Model is the most accurate model (first, 37.18\% of the time) followed by the Performance Matched Model (first, 32.10\% of the time). Thus, I conclude that the Modified Forward-Looking Model is the most accurate model among those tested in terms of estimating the magnitude of managed earnings. 
Table 6. Accuracy Analyses

Panel A: Bias and Accuracy

\begin{tabular}{|c|c|c|c|c|}
\hline & \multicolumn{2}{|l|}{ Bias } & \multicolumn{2}{|l|}{ Accuracy } \\
\hline & Mean & Median & Mean & Median \\
\hline Jones Model & $0.007 *$ & $0.014 * * *$ & $0.070 * * *$ & $0.049 * * *$ \\
\hline Modified Jones Model & $0.008 * *$ & $0.015 * * *$ & $0.070 * * *$ & $0.048 * * *$ \\
\hline Lagged Model & 0.006 & $0.009 * * *$ & $0.069 * * *$ & $0.048 * * *$ \\
\hline Performance Matched Model & $-0.006^{*}$ & -0.001 & $0.064 * * *$ & $0.045^{* * *}$ \\
\hline Modified FL Model & -0.003 & -0.003 & $0.074 * * *$ & $0.046 * * *$ \\
\hline
\end{tabular}

Note. Bias $=\mathrm{DA}^{*}-\mathrm{DA}$, Accuracy $=\left|\mathrm{DA}^{*}-\mathrm{DA}\right|$, where DA* $=$ Earnings original - Earnings restated.

$* * * \mathrm{p}$ value $<1 \%$, ** $\mathrm{p}$ value $<5 \%$, $*$ p value $<10 \%$

Panel B: \% of the time each rank is obtained, based on ranking by accuracy

\begin{tabular}{llllll}
\hline & $\begin{array}{l}\text { First } \\
(\%)\end{array}$ & $\begin{array}{l}\text { Second } \\
(\%)\end{array}$ & $\begin{array}{l}\text { Third } \\
(\%)\end{array}$ & $\begin{array}{l}\text { Fourth } \\
(\%)\end{array}$ & $\begin{array}{l}\text { Fifth } \\
(\%)\end{array}$ \\
\hline Jones Model & 9.01 & 16.74 & 25.64 & 28.98 & 19.63 \\
Modified Jones Model & 4.73 & 15.70 & 24.83 & 32.79 & 21.94 \\
Lagged Model & 16.97 & 17.21 & 29.68 & 15.70 & 20.44 \\
Performance Matched Model & 32.10 & 28.64 & 13.16 & 13.51 & 12.59 \\
Modified FL Model & 37.18 & 21.71 & 6.70 & 9.01 & 25.40 \\
& & & & & 100.00 \\
& 100.00 & 100.00 & 100.00 & 100.00
\end{tabular}

For each observation, models are ranked from first to fifth based on the value of accuracy. Then I calculate the percentage of the models for each ranking.

\subsection{Analyses for REV-Subsample}

I repeat the previous analyses for the REV-Subsample. Table 7 reports the results of earnings management detection analyses for REV-Subsample. Comparison of discretionary accruals (Panel A) shows that the Lagged Model and the Modified Forward-Looking Model generate significant differences (both mean and median) of discretionary accruals between the non-restated and restated firms. The contingency-table tests (Panel B) indicate the Modified Forward-Looking Model generates significant differences in the proportion of restatement firms in the high versus low discretionary accruals quintiles. Logistic regression analysis (Panel C) indicates the Lagged Model and the Modified Forward-Looking Model outperform the other models. Thus, all three tests show that the Modified Forward-Looking Model is more powerful than the other models at detecting earnings management that is accomplished through revenue manipulation. 
Table 7. REV-Subsample Earnings Management Detection Analyses

(84 observations of restatement and 5439 observations of non-restatement)

Panel A: Comparison of discretionary accruals

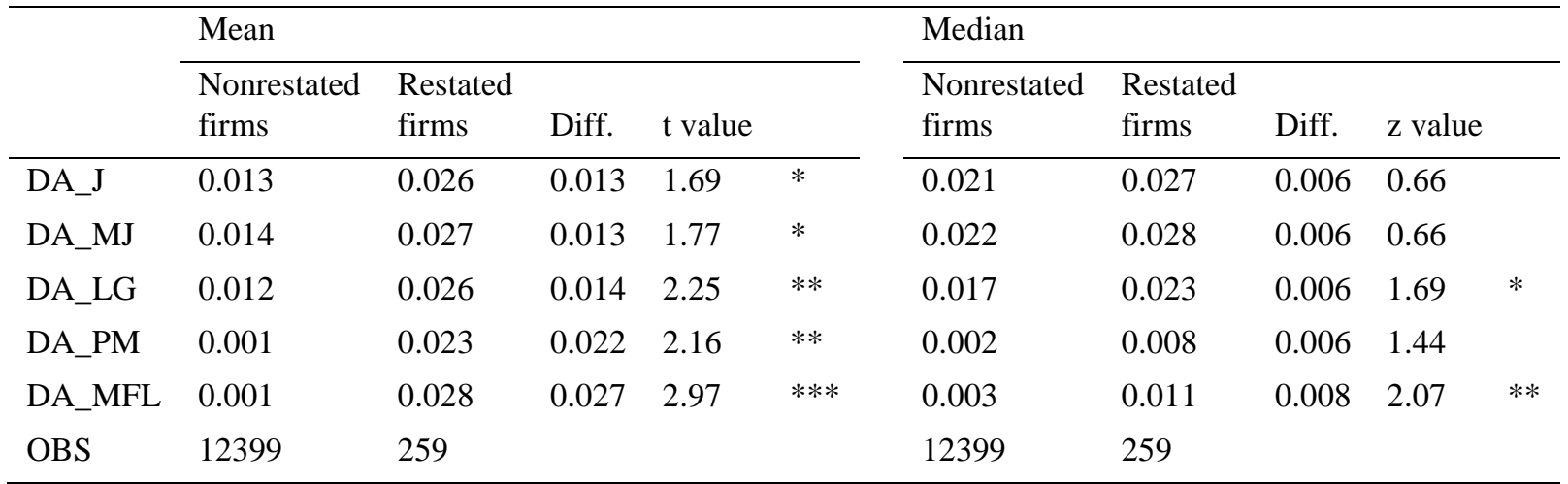

Panel B: Contingency-Table Test

Association between absolute value of discretionary accruals and financial statements restatements

\begin{tabular}{|c|c|c|c|c|c|c|c|c|c|c|}
\hline \multirow[b]{2}{*}{ Restated } & \multicolumn{2}{|c|}{ Jones Model } & \multicolumn{2}{|c|}{$\begin{array}{l}\text { Modified } \\
\text { Jones }\end{array}$} & \multicolumn{2}{|c|}{ Lagged Model } & $\begin{array}{l}\text { Perfo } \\
\text { Matc } \\
\text { Mod }\end{array}$ & $\begin{array}{l}\text { nance } \\
\text { ed }\end{array}$ & \multicolumn{2}{|c|}{$\begin{array}{l}\text { Modified } \\
\text { Model }\end{array}$} \\
\hline & Yes & No & Yes & No & Yes & No & Yes & No & Yes & No \\
\hline High DA & 62 & 2469 & 61 & 2470 & 60 & 2471 & 58 & 2473 & 69 & 2462 \\
\hline Low DA & 54 & 2477 & 54 & 2477 & 45 & 2486 & 58 & 3473 & 40 & 2491 \\
\hline $\mathrm{p}$ value & & 0.255 & & 0.2858 & & 0.0835 & & 0.5374 & & 0.0032 \\
\hline
\end{tabular}

Ha: The proportion of restatement firms in the high discretionary accruals quintile is greater than the proportion of restatement firms in the low discretionary accruals quintile

Panel C: Logistic Regression

\begin{tabular}{|c|c|c|c|c|c|c|}
\hline & & $\begin{array}{l}\text { Expected } \\
\text { Sign }\end{array}$ & $\begin{array}{l}\text { Parameter } \\
\text { estimates }\end{array}$ & $\begin{array}{l}\text { Prob }>\chi^{2} \\
\text { p-value }\end{array}$ & $\begin{array}{l}\text { Odds } \\
\text { Ratio }\end{array}$ & $\begin{array}{l}\text { Log } \\
\text { Likelihood }\end{array}$ \\
\hline \multirow[t]{2}{*}{ Jones Model } & b1 & + & 1.079 & 0.1247 & 2.943 & 2446 \\
\hline & $\mathrm{b} 2$ & - & 2.776 & 01615 & 16.061 & \\
\hline \multirow[t]{2}{*}{ Modified Jones } & $\mathrm{b} 1$ & + & 1.143 & 0.1018 & 3.137 & 2446 \\
\hline & $\mathrm{b} 2$ & - & 2.263 & 0.2732 & 9.614 & \\
\hline \multirow[t]{2}{*}{ Lagged Model } & b1 & + & 1.371 & 0.0613 & 3.941 & 2446 \\
\hline & $\mathrm{b} 2$ & - & 0.828 & 0.5449 & 2.289 & \\
\hline \multirow[t]{2}{*}{ Performance Matched Model } & b1 & + & 0.957 & 0.2468 & 2.603 & 2446 \\
\hline & b2 & - & 1.525 & 0.2210 & 4.594 & \\
\hline \multirow[t]{2}{*}{ Modified FL Model } & b1 & + & 1.088 & 0.0231 & 2.967 & 2448 \\
\hline & $\mathrm{b} 2$ & - & -0.287 & 0.7485 & 0.750 & \\
\hline
\end{tabular}


Table 8. REV-Subsample Accuracy Analyses

Panel A: Bias and Accuracy

\begin{tabular}{|c|c|c|c|c|}
\hline & \multicolumn{2}{|l|}{ Bias } & \multicolumn{2}{|l|}{ Accuracy } \\
\hline & Mean & Median & Mean & Median \\
\hline Jones Model & 0.008 & $0.012 * *$ & $0.082 * * *$ & $0.058 * * *$ \\
\hline Modified Jones Model & 0.009 & $0.013 * * *$ & $0.082 * * *$ & $0.057 * * *$ \\
\hline Lagged Model & 0.007 & $0.013 * * *$ & $0.083 * * *$ & $0.059 * * *$ \\
\hline Performance Matched Model & $-0.012 *$ & -0.005 & $0.072 * * *$ & $0.050 * * *$ \\
\hline Modified FL Model & -0.005 & -0.000 & $0.082 * * *$ & $0.050 * * *$ \\
\hline
\end{tabular}

Note. Bias $=\mathrm{DA}^{*}-\mathrm{DA}$, Accuracy $=\left|\mathrm{DA}^{*}-\mathrm{DA}\right|$, where DA* $=$ Earnings original - Earnings restated .

$* * * \mathrm{p}$ value $<1 \%$, ** $\mathrm{p}$ value $<5 \%, * \mathrm{p}$ value $<10 \%$

Panel B: \% of the time each rank is obtained, based on ranking by accuracy

\begin{tabular}{llllll}
\hline & $\begin{array}{l}\text { First } \\
(\%)\end{array}$ & $\begin{array}{l}\text { Second } \\
(\%)\end{array}$ & $\begin{array}{l}\text { Third } \\
(\%)\end{array}$ & $\begin{array}{l}\text { Fourth } \\
(\%)\end{array}$ & $\begin{array}{l}\text { Fifth } \\
(\%)\end{array}$ \\
\hline Jones Model & 7.34 & 15.06 & 25.10 & 30.89 & 21.62 \\
Modified Jones Model & 5.41 & 14.67 & 20.46 & 34.75 & 24.71 \\
Lagged Model & 14.29 & 14.29 & 34.36 & 13.13 & 23.94 \\
Performance Matched Model & 33.20 & 33.20 & 13.90 & 11.20 & 8.49 \\
Modified FL Model & 39.77 & 22.78 & 6.18 & 10.04 & 21.24 \\
& 100.00 & 100.00 & 100.00 & 100.00 & 100.00
\end{tabular}

Table 8 reports the results of accuracy analyses. Panel A (Bias and Accuracy) shows that the Modified Forward-Looking Model generates the smallest bias measures (mean 0.005 and median -0.000). (Note 12) Panel B (Rankings of accuracy) indicates that the Modified Forward-Looking Model is more accurate than all other models (first, 39.77\% of the time) followed by Performance Matched Model (first, 33.20\% of the time). According to the results of Panel A and B, I conclude that the Modified Forward-Looking Model is more accurate than the other models.

\subsection{Analyses for EXP-Subsample}

Table 9 and Table 10 report the results for EXP-Subsample. Table 9 documents the results of earnings management detection analyses. Comparison of discretionary accruals (Panel A) shows that only the Modified Forward-Looking Model generates significant difference (mean) of discretionary accruals between the non-restated and restated firms. The contingency-table tests (Panel B) show only the Modified Forward-Looking Model generates significant difference in the proportion of restatement firms in high versus low discretionary accruals quintiles. Logistic regression analysis (Panel C) indicates the Modified Forward-Looking Model outperforms all of the other models based on examining the coefficients of both DA and NDA. Thus, all three tests show that the Modified Forward-Looking Model is more powerful than the other models at detecting earnings management that is accomplished through expense manipulation.

Table 10 reports the results of accuracy analyses. The results of Panel A shows that the Performance Matched Model and the Modified Forward-Looking Model generates insignificant bias measures. All the accuracy measures are significant. Panel B (Ranking of Accuracy) shows that the Modified Forward-Looking Model is more accurate than all other models (first, 35.67\% of the time). Thus, I conclude that the Modified Forward-Looking Model is more accurate than the other models. 
Table 9. EXP-Subsample Earnings Management Detection Analyses

(457 observations of restatement and 12532 observations of non-restatement)

Panel A: Comparison of Discretionary Accruals

\begin{tabular}{|c|c|c|c|c|c|c|c|c|c|}
\hline & \multicolumn{5}{|l|}{ Mean } & \multicolumn{4}{|l|}{ Median } \\
\hline & $\begin{array}{l}\text { Nonrestated } \\
\text { firms }\end{array}$ & $\begin{array}{l}\text { Restated } \\
\text { firms }\end{array}$ & Diff. & $\mathrm{t}$ value & & $\begin{array}{l}\text { Nonrestated } \\
\text { firms }\end{array}$ & $\begin{array}{l}\text { Restated } \\
\text { firms }\end{array}$ & Diff. & $\mathrm{z}$ value \\
\hline DA_J & 0.013 & 0.014 & 0.001 & 0.41 & & 0.021 & 0.021 & -0.000 & -0.62 \\
\hline DA_MJ & 0.014 & 0.016 & 0.002 & 0.36 & & 0.022 & 0.022 & 0.000 & 0.23 \\
\hline DA_LG & 0.011 & 0.012 & -0.001 & -0.31 & & 0.017 & 0.014 & -0.003 & -0.62 \\
\hline DA_PM & -0.003 & 0.001 & 0.005 & 0.97 & & 0.001 & 0.004 & 0.003 & 0.52 \\
\hline DA_MFL & 0.000 & 0.013 & 0.013 & 2.51 & $* * *$ & 0.002 & 0.006 & 0.004 & 1.00 \\
\hline OBS & 12532 & 457 & & & & 12532 & 457 & & \\
\hline
\end{tabular}

Panel B: Contingency-Table Tests

\begin{tabular}{|c|c|c|c|c|c|c|c|c|c|c|}
\hline & Jones $\mathrm{N}$ & del & $\begin{array}{l}\text { Modifie } \\
\text { Model }\end{array}$ & Jones & Lagged & Model & $\begin{array}{l}\text { Perform } \\
\text { Matche }\end{array}$ & $\begin{array}{l}\text { Model } \\
\text { Moe }\end{array}$ & $\begin{array}{l}\text { Modified } \\
\text { Model }\end{array}$ & $\mathrm{FL}$ \\
\hline Restated & Yes & No & Yes & No & Yes & No & Yes & No & Yes & No \\
\hline High DA & 75 & 2523 & 72 & 2526 & 79 & 2519 & 68 & 2530 & 112 & 2486 \\
\hline Low DA & 96 & 2501 & 97 & 2500 & 94 & 2503 & 93 & 2504 & 75 & 2522 \\
\hline $\mathrm{p}$ value & 0.9568 & & 0.9793 & & 0.8925 & & 0.9816 & & 0.0036 & \\
\hline
\end{tabular}

Ha: The proportion of restatement firms in the high discretionary accruals quintile is greater than the proportion of restatement firms in the low discretionary accruals quintile

Panel C: Logistic Regression

\begin{tabular}{|c|c|c|c|c|c|c|}
\hline & & $\begin{array}{l}\text { Expected } \\
\text { Sign }\end{array}$ & $\begin{array}{l}\text { Parameter } \\
\text { estimates }\end{array}$ & $\begin{array}{l}\text { Prob }>\chi^{2} \\
\text { p-value }\end{array}$ & $\begin{array}{l}\text { Odds } \\
\text { Ratio }\end{array}$ & $\begin{array}{l}\text { Log } \\
\text { Likelihood }\end{array}$ \\
\hline \multirow[t]{2}{*}{ Jones Model } & $\mathrm{b} 1$ & + & 0.385 & 0.5235 & 1.469 & 3511 \\
\hline & b2 & $0 /-$ & -0.453 & 0.7406 & 0.636 & \\
\hline \multirow[t]{2}{*}{ Modified Jones } & b1 & + & 0.434 & 0.4710 & 1.543 & 3510 \\
\hline & b2 & $0 /-$ & -0.889 & 0.5248 & 0.411 & \\
\hline \multirow[t]{2}{*}{ Lagged Model } & $\mathrm{b} 1$ & + & 0.431 & 0.4963 & 1.539 & 3511 \\
\hline & b2 & $0 /-$ & 0.111 & 0.9137 & 1.118 & \\
\hline \multirow[t]{2}{*}{ Performance Matched Model } & b1 & + & 0.896 & 0.2043 & 2.450 & 3509 \\
\hline & b2 & $0 /-$ & -0.631 & 0.4660 & 0.532 & \\
\hline \multirow[t]{2}{*}{ Modified FL Model } & b1 & + & 0.9247 & 0.0374 & 2.521 & 3507 \\
\hline & b2 & $0 /-$ & -1.0873 & 0.5661 & 0.337 & \\
\hline
\end{tabular}


Table 10. EXP-Subsample Accuracy Analyses

Panel A: Bias and Accuracy

\begin{tabular}{llllll}
\hline & \multicolumn{2}{l}{ Bias } & & & \multicolumn{2}{l}{ Accuracy $^{\mathrm{a}}$} \\
\cline { 2 - 3 } \cline { 5 - 6 } & Mean & Median & & Mean & Median \\
\hline Jones Model & $0.009^{* *}$ & $0.017^{* * *}$ & & $0.063^{* * * *}$ & $0.043^{* * *}$ \\
Modified Jones Model & $0.010^{* *}$ & $0.019^{* * *}$ & & $0.063^{* * *}$ & $0.044^{* * *}$ \\
Performance Matched Model & 0.005 & $0.008^{* *}$ & & $0.063^{* * *}$ & $0.045^{* * *}$ \\
Lagged Model & -0.005 & -0.002 & & $0.060^{* * *}$ & $0.044^{* * *}$ \\
Modified FL Model & -0.001 & 0.003 & & $0.062^{* * *}$ & $0.045^{* * *}$
\end{tabular}

Note. Bias $=\mathrm{DA}^{*}-\mathrm{DA}$, Accuracy $=\left|\mathrm{DA}^{*}-\mathrm{DA}\right|$, where DA* $=$ Earnings original - Earnings ${ }_{\text {restated }}$.

$* * * \mathrm{p}$ value $<1 \%$, ** $\mathrm{p}$ value $<5 \%$, $* \mathrm{p}$ value $<10 \%$

Panel B: \% of times each rank is obtained, based on ranking by firm

\begin{tabular}{llllll}
\hline & $\begin{array}{l}\text { First } \\
(\%)\end{array}$ & $\begin{array}{l}\text { Second } \\
(\%)\end{array}$ & $\begin{array}{l}\text { Third } \\
(\%)\end{array}$ & $\begin{array}{l}\text { Fourth } \\
(\%)\end{array}$ & $\begin{array}{l}\text { Fifth } \\
(\%)\end{array}$ \\
\hline Jones Model & 8.75 & 16.63 & 26.91 & 29.98 & 17.72 \\
Modified Jones Model & 4.38 & 15.54 & 28.01 & 30.42 & 21.66 \\
Lagged Model & 17.07 & 18.60 & 25.82 & 17.51 & 21.01 \\
Performance Matched Model & 34.14 & 27.13 & 12.04 & 13.57 & 13.13 \\
Modified FL Model & 35.67 & 22.10 & 7.22 & 8.53 & 26.48 \\
& 100.00 & 100.00 & 100.00 & 100.00 & 100.00 \\
\hline
\end{tabular}

In summary, I find that the Modified Forward-Looking Model is the most powerful model at detecting earnings management and the most accurate model in terms of estimating the magnitude of managed earnings for the pooled sample, REV-subsample, and EXP-subsample. The superior performance of the Modified Forward-Looking Model is attributed to the two adjustments I proposed: (1) using analysts' long term earnings growth forecasts as a proxy for long term sales growth; and (2) including ROA to control for performance. These two adjustments mitigate the concerns about discretionary accrual models in the prior literature (McNichols 2000, Kothari et al. 2005, Kang and Sivaramakrishnan 1995, Kang 1999).

The Modified Jones Model is designed to eliminate the tendency of the Jones Model to measure discretionary accruals with error when discretion is exercised over revenues. Thus, the Modified Jones Model should outperform the Jones Model for the REV-Subsample. However, the results indicate that the performance of the two models is similar. For example, Table 7, Panel A (Comparison of Discretionary Accruals) shows that the mean differences of discretionary accruals between the non-restated and restated firms generated from the Modified Jones Model and the Jones Model are the same, 0.013 (p values are 0.08 and 0.09 , respectively). The contingency-table test and logistic regression also indicate that the two models perform similarly.

For the EXP-Subsample, the performance of the Modified Jones Model and the Jones Model are similar as well. For example, Table 9, Panel A (Comparison of Discretionary Accruals) shows that the mean differences of discretionary accruals between the non-restated and restated firms generated from the Modified Jones Model and the Jones Model are 0.002 and 0.001 , respectively ( $\mathrm{p}$ values are 0.36 and 0.41 , respectively). The contingency-table test and logistic regression reach the same conclusion. 
One possible explanation is that both the Modified Jones Model and the Jones Model do not control for performance. Dechow et al. (1995) find that for firms with extreme financial performance, the Modified Jones Model and the Jones Model perform similarly (Dechow et al. 1995, Table 3). They state that this evidence suggests that before making any earning management inference, the researcher should ensure that the results are not induced by omitted variables correlated with earnings performance (p.209). It is reasonable to state that the earnings restatement firms are extreme firms with extreme financial performance. Thus, it may be more important for these firms to control for performance when estimating the discretionary accruals. Stated more directly, the effect of performance on estimating discretionary accruals dominates the effects of other factors. Moreover, the results show that the Performance-Matched Modified Jones Model outperforms the Modified Jones Model and the Jones Model, which further indicates the importance of performance matching.

\section{Conclusion}

Prior studies yield conflicting results on the ability of alternative discretionary accrual models to decompose total accruals into discretionary accruals and non-discretionary accruals. Thus, whether discretionary accrual models can accurately decompose total accruals into discretionary and non-discretionary components and, thereby, detect earnings management is still an open empirical question.

This paper seeks to assess the relative performance of extant discretionary accrual models (including some newly-refined models) using a sample of firms that issued earnings restatements from 1994 to 2005. Using restatement firms provides a unique setting in which to test the descriptive validity of alternative discretionary accrual models. The sample represents firms for which (1) earnings management has occurred; and (2) the amount of the earnings management can be quantified. Thus, this enables me to examine the performance of discretionary accrual models along two dimensions: (1) the ability to detect the existence of earnings management; and (2) the ability to estimate the magnitude of the amount of earnings that is managed.

Earnings management detection analyses involve three tests: comparison of discretionary accruals between non-restatement and restatement firms, contingency-table tests to examine the association between the discretionary accruals and restatement, and logistic regression analysis to examine how well the discretionary versus non-discretionary accruals predicts the likelihood of restatement. The results from these three tests indicate that the Modified Forward-Looking Model does the best job of detecting earnings management among the models tested.

Accuracy analyses show that the Modified Forward-Looking Model is the most accurate model relative to the other models tested. However, it still does not accurately estimate the magnitude of earnings that is managed.

For the subsamples of earnings managed through revenues and earnings managed through expenses, the Modified Forward-Looking Model outperforms the other models in terms of both earnings management detection and the ability to estimate the magnitude of managed earnings. The alternative discretionary accrual models evaluated in this paper do not show any tendency of performing better in one subsample than the other subsample. For example, the Modified Jones Model does not perform better than the Jones Model for the subsample of earnings managed through revenues, even though the Modified Jones Model is designed to correct the tendency of the Jones Model to measure discretionary accruals with error when discretion is exercised over revenues. One possible explanation is these firms are extreme firms with extreme financial performance. Thus, it is important to control for performance when estimating the discretionary accruals. One caveat should be mentioned that the application of the modified forward-looking model is limited to firms with analysts following.

This study contributes to the extant accounting research literature, especially for earnings management research in several ways. First, prior studies tend to focus on the role of discretionary accruals in testing for an association between earnings management and discretionary accruals. This paper provides evidence of using both discretionary and non-discretionary accruals to evaluate the discretionary accruals models' ability to detect earnings management. The results suggest that including non-discretionary accruals is helpful to evaluate the performance of alternative discretionary accrual models. Second, the results reported here indicate the importance of performance matching (Kothari et al 2005). I find that the Performance Matched Model and the Modified Forward-Looking Model outperform the other models that do not control for performance.

However, the results must be interpreted with caution. Since the tests assess the performance of the alternative discretionary accrual models under the financial statement restatement setting, the findings may not be generalized to firms with moderate levels of earnings management, e.g., firms engaging in earnings management within Generally Accepted Accounting Principles (GAAP). Thus, one avenue for future research may be to test the performance of the Modified Forward-Looking Model along with other models in other settings, such as the discontinuity of earnings 
frequency distribution at benchmarks. In addition, all the discretionary accrual models evaluated in this study are not accurate in estimating the magnitude of the managed earnings despite the superior performance of the Modified Forward-Looking Model. Thus, future research may continue to work on developing better economic models of discretionary accruals along two directions: (1) to better control for the performance; and (2) to select appropriate variables to mitigate the correlated omitted variable problem.

\section{References}

Ali, A., T. Chen, \& S. Radhakrishnan. (2007). Corporate disclosure y family firms. Journal of Accounting and Economics, 44, 238-286. https://doi.org/10.1016/j.jacceco.2007.01.006

Beniesh, M. \& M. Vargus. (2002). Insider trading, earnings quality, and accrual mispricing. The Accounting Review, 77(October), 755-792. https://doi.org/10.2308/accr.2002.77.4.755

Botsari, A. \& G. Meeks. (2008). Do acquirers manage earnings prior to a shre for share bid? Journal of Business Finance and Accounting, 35, 633-670. https://doi.org/10.1111/j.1468-5957.2008.02091.x

Collins, D. \& P. Hribar. (2002). Errors in estimating accruals: implications for empirical research. Journal of Accounting Research, 40(March): 105-134.

Dechow, P., R. Sloan, \& A. Sweeney. (1995). Detecting earnings management. The Accounting Review, 70(April): 193-225.

Dechow, P., R. Sloan, \& A. Sweeney. (1996). Causes and consequences of earnings manipulation: An analysis of firms subject to enforcement actions by the SEC. Contemporary Accounting Research, 13(Spring): 1-36.

Dechow, P., S. Richardson, \& I. Tuna. (2003). Why are earnings kinky? An examination of the earnings management explanation. Review of Accounting Studies, 2(June-September): 355-384. https://doi.org/10.1023/A:1024481916719

Fields, T., Lys, T., \& Vincent, L. (2001). Empirical research on accounting choice. Journal of Accounting \& Economics, 32, 255-307. https://doi.org/10.1016/S0165-4101(01)00028-3

General Accounting Office. (2002). Financial statement restatements: Trends, market impacts, regulatory responses, and remaining challenges. Washington, DC, GAO-38-138.

General Accounting Office. (2006). Financial restatements: Update of public company trends, market impacts, regulatory enforcement activities. Washington, DC, GAO-06-678.

Jones, K. L., Krishnan, G. V. \& Melendrez, K. D. (2008). Do models of discretionary accruals detect actual cases of fraudulent and restated earnings? An empirical analysis. Contemporary Accounting Research, 25, 499-531. https://doi.org/10.1506/car.25.2.8

Kang, S.H., \& K. Sivaramakrishnan. (1995). Issues in testing earnings management and an instrumental variable approach. Journal of Accounting Research, 33(Autumn), 353-367. https://doi.org/10.2307/2491492

Kang, S.H. (1999). A conceptual and empirical evaluation of accrual prediction models. Working paper. https://doi.org/10.2139/ssrn.147259

Kasznik, R. (1999). On the association between voluntary disclosure and earnings management. Journal of Accounting Research, 37(Spring), 57-81. https://doi.org/10.2307/2491396

Kothari, S.P. (2001). Capital markets research in accounting. Journal of Accounting \& Economics, 32, 105-231. https://doi.org/10.1016/S0165-4101(01)00030-1

Kothari, S.P., A. Leone, \& C. Wasley. (2005). Performance matched discretionary accrual measures. Journal of Accounting and Economics, 39, 163-197. https://doi.org/10.1016/j.jacceco.2004.11.002

Kothari, S. P., N. Mizik, \& S. Roychowdhury. (2016). Managing for the moment: the role of earnings management via real activities versus accruals in SEO valuation. The Accounting Review, 91(2), 559-586. https://doi.org/10.2308/accr-51153

Larcker, D., S. Richardson, \& I. Tuna. (2007). Corporate governance, accounting outcomes, and organizational performance. The Accounting Review, 82(4), 963-1008. https://doi.org/10.2308/accr.2007.82.4.963

Lawrence, A., M. Minutti-Meza, \& P. Zhang. (2011). Can big 4 versus non-big 4 differences in audit quality proxies be attributed to client characteristics? The Accounting Review, 86(1), 259-286. https://doi.org/10.2308/accr.00000009 
McNichols, M. (2000). Research design issues in earnings management studies. Journal of Accounting and Public Policy, 19(Winter), 313-345. https://doi.org/10.1016/S0278-4254(00)00018-1

Peasnell, K. V., P. F. Pope, \& S. Young. (2000). Detecting earnings management using cross-sectional abnormal accruals models. Accounting \& Business Research, 30(Autumn), 313-326. https://doi.org/10.1080/00014788.2000.9728949

Prawitt, D., J. Smith, \& D. Wood. (2009). Former audit partners and abnormal accruals. The Accounting Review, 84(4), 1255-1280. https://doi.org/10.2308/accr.2009.84.4.1255

Richardson, S., I. Tuna, \& M. Wu. (2002). Predicting earnings management: the case of earnings management. Working paper.

Subramanyam, K. R. (1996). The pricing of discretionary accruals. Journal of Accounting and Economics, 22(August - December), 249-281. https://doi.org/10.1016/S0165-4101(96)00434-X

Teoh, S., I. Welch, \& T. Wong. (1998). Earnings management and the underperformance of seasoned equity offerings. Journal of Financial Economics, (October), 63-99. https://doi.org/10.1016/S0304-405X(98)00032-4

Thomas, J. \& X. Zhang. (2000). Identifying unexpected accruals: a comparison of current approaches. Journal of Accounting and Public Policy, 19(Winter), 347-376. https://doi.org/10.1016/S0278-4254(00)00016-8

Xie, B., W. N. Davidson, \& P. J. DaDalt. (2003). Earnings Management and Corporate Governance: The Roles of the Board and the Audit Committee. Journal of Corporate Finance, 9(3), 295-316. https://doi.org/10.1016/S0929-1199(02)00006-8 


\section{Appendix A. Discretionary Accrual Models tested in this paper.}

- The Jones Model

TACC $_{i t}=\alpha+\beta_{1}\left(1 /\right.$ TA $\left._{i t-1}\right)+\beta_{2}\left(\Delta\right.$ SALES $\left._{i t}\right)+\beta_{3} \mathrm{PPE}_{\mathrm{it}}+\varepsilon_{\mathrm{it}}$

- The Modified Jones Model (MJ)

$\mathrm{TACC}_{\mathrm{it}}=\alpha+\beta_{1}\left(1 / \mathrm{TA} \mathrm{it}_{-1}\right)+\beta_{2}\left(\Delta \mathrm{SALES}_{\mathrm{it}}-\Delta \mathrm{AR}_{\mathrm{it}}\right)+\beta_{3} \mathrm{PPE}_{\mathrm{it}}+\varepsilon_{\mathrm{it}}$

- The Lagged Model (LG)

$\mathrm{TACC}_{\mathrm{it}}=\alpha+\beta_{1}\left(1 / \mathrm{TA}_{\mathrm{it}-1}\right)+\beta_{2}\left((1+\mathrm{k}) \Delta \mathrm{SALES}_{\mathrm{it}}-\Delta \mathrm{AR}_{\mathrm{it}}\right)+\beta_{3} \mathrm{PPE}_{\mathrm{it}}+\beta_{4} \mathrm{TACC}_{\mathrm{it}-1}+\varepsilon_{\mathrm{it}}$

- The Performance Matched Modified Jones Model (PM)

$\mathrm{TACC}_{\mathrm{it}}=\alpha+\beta_{1}\left(1 / \mathrm{TA}_{\mathrm{it}-1}\right)+\beta_{2}\left(\Delta \mathrm{SALES}_{\mathrm{it}}-\Delta \mathrm{AR}_{\mathrm{it}}\right)+\beta_{3} \mathrm{PPE}_{\mathrm{it}}+\beta_{4} \mathrm{ROA}_{\mathrm{it}} \varepsilon_{\mathrm{it}}$

- The Modified Forward-Looking Model (MFL)

$\mathrm{TACC}_{\mathrm{it}}=\alpha+\beta_{1}\left(1 / \mathrm{TA} \mathrm{it}_{-1}\right)+\beta_{2}\left((1+\mathrm{k}) \Delta \mathrm{SALES} \mathrm{it}_{\mathrm{it}}-\Delta \mathrm{AR}_{\mathrm{it}}\right)+\beta_{3} \mathrm{PPE}_{\mathrm{it}}+$

$$
\beta_{4} \text { TACC }_{\text {it }-1}+\beta_{5} \text { EST_GROWTH }_{\text {it }}+\beta_{6} \text { ROA }_{i t}+\varepsilon_{i t}
$$

\section{Variable definitions (Please refer to text for more details):}

\begin{tabular}{|c|c|c|}
\hline TACC & $=$ & Total accruals, (EBXI - CFO) scaled by beginning total assets (AT). \\
\hline EBXI & $=$ & $\begin{array}{l}\text { Earnings before extraordinary items and discontinued operations (IBC) scaled by } \\
\text { beginning total assets (AT). }\end{array}$ \\
\hline $\mathrm{CFO}$ & $=$ & $\begin{array}{l}\text { Cash Flows from Operation (OANCF- XIDOC) scaled by beginning total assets } \\
\text { (AT). }\end{array}$ \\
\hline$\triangle$ SALES & $=$ & The change in firm i's sales (SALE) from year $\mathrm{t}-1$ to $\mathrm{t}$ scaled by beginning total assets. \\
\hline$\Delta \mathrm{AR}$ & $=$ & $\begin{array}{l}\text { The change in firm i's accounts receivable from year t- } 1 \text { to } t \text { (RECCH) scaled by } \\
\text { beginning total assets. }\end{array}$ \\
\hline PPE & $=$ & $\begin{array}{l}\text { Firm i's year } t \text { gross property, plant, and equipment (PPEGT) scaled by beginning } \\
\text { total assets. }\end{array}$ \\
\hline ROA & $=$ & Firm i's return on assets of year $t$. \\
\hline $\mathrm{k}$ & $=$ & $\begin{array}{l}\text { The regression coefficient from a regression } \\
\Delta \mathrm{AR}_{\mathrm{it}}=\alpha+\mathrm{k} \Delta \mathrm{SALES}_{\mathrm{it}}+\varepsilon_{\mathrm{it}} \text { for each two-digit SIC-year grouping. }\end{array}$ \\
\hline LTACC & $=$ & Firm i's total accruals at year t-1. \\
\hline GR_SALES & $=$ & The change in firm i's sales (SALE) from year $t$ to $t+1$ scaled by year $t$ sales. \\
\hline $\begin{array}{l}\text { EST_ }_{-} \\
\text {GROWTH }\end{array}$ & $=$ & $\begin{array}{l}\text { The median of analysts' long-term earnings growth forecasts for the last month of } \\
\text { year t. }\end{array}$ \\
\hline DA_J & $=$ & Discretionary accruals estimated from Jones Model. \\
\hline DA_MJ & $=$ & Discretionary accruals estimated from Modified Jones Model. \\
\hline DA_LG & $=$ & Discretionary accruals estimated from the Lagged Model \\
\hline DA_PM & $=$ & Discretionary accruals estimated from Performance Matched Model. \\
\hline DA_MFL & $=$ & Discretionary accruals estimated from Modified Forward-Looking Model \\
\hline $\mathrm{DA}^{*}$ & $=$ & Earnings $_{\text {original }}-$ Earnings $_{\text {restated. }}$. \\
\hline
\end{tabular}




\section{Notes}

Note 1. I hand collect the originally reported earnings and restated earnings for this purpose. Even though recent studies use Audit Analytics for restatements, Audit Analytics only identifies the restatement years without the orginial and restatement amounts. So without hand-collected data, it is impossible to calculate the amount of managed earnings.

Note 2. For example, Dechow et al. (1995) conclude the Modified Jones Model exhibits the most power in detecting earnings management; Thomas and Zhang (2000) find the Kang-Sivaramakrishnan Model (hereafter KS Model) performs moderately well in term of accuracy; Kothari et al. (2005) find that the Performance-Matched Modified Jones Model is better than the others. Dechow et al. (2003) conclude the Forward-Looking Model has the most explanatory power.

Note 3. For example, the Lagged Model and the Forward-Looking Model from Dechow et al. (2003), and the Performance - Matched Modified Jones Model from Kothari et al. (2005).

Note 4. The models evaluated in this paper are Jones Model, Modified Jones Model, Lagged Model, Performance Matched Modified Jones Model, and Modified Forward-Looking Model.

Note 5. I subtract the cash portion of discontinued operations and extraordinary items (XIDOC) from total cash from operations to provide a cash flow from continuing operations. This cash flow definition is consistent with the definition of net income.

Note 6. Dechow et al (2003) use the Lagged Model for their analyses.

Note 7. Ideally, I would like to use analysts' long-term sales forecasts. However, sales forecasts are only available for a limited number of firms followed by IBES and Value Line. Thus, I use analysts' long-term earnings forecasts instead. I performed correlation test of sales and earnings long-term forecasts. The Pearson (Spearman) correlation coefficient is $0.5583(0.8046)$. All the coefficients are highly significant (the p values are less than 0.0001 ).

Note 8. The GAO defines an accounting irregularity as "an instance in which a company restates its financial statements because they were not fairly presented in accordance with generally accepted accounting principles (GAAP)" (GAO, 2002, p.2).

Note 9. The restated fiscal years range from 1991 to 2005.

Note 10. Notice that I have 866 restated firms and 18,739 non-restated firms. The proportion of restated firms in the sample is $4.41 \%$.

Note 11. For example, Panel A (the regression only has DA as an independent variable) shows PM model is good at detecting earnings management while Panel B (the regression has both DA and NDA) shows it is not.

Note 12. All the accuracy measures are significantly different from zero. 